GEOLOGICAL SURVEY CIRCULAR 902-A-P

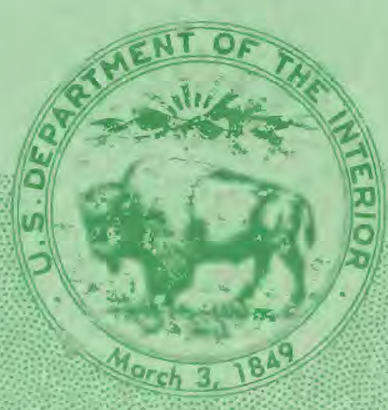

Petroleum Potential of Wilderness Lands in the Western United States 


\section{Petroleum Potential of Wilderness Lands in the Western United States}

By Betty M. Miller, editor
GEOLOGICAL SURVEY
CIRCULAR
$902-A-P$

An assessment of the petroleum resources of Wilderness Lands in the Western United States. A brief description of the geologic framework and the petroleum geology for the Wilderness Lands in each of the 11 Western States 


\section{United States Department of the Interior}

JAMES G. WATT, Secretary

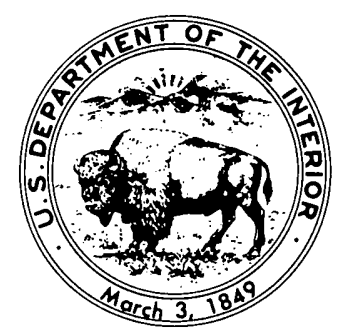

\section{Geological Survey}

Dallas L. Peck, Director 


\section{CONTENTS}

Abstract, by Betty M. Miller

Acknowledgments

Chapter:

A. Petroleum resource assessments of the Wilderness Lands in the Western United States, by Betty M. Miller

B. Digital cartography, by Michael A. Domaratz and Jo Anne Stapleton

C. Petroleum potential of Wilderness Lands in Arizona, by Robert T. Ryder

D. Petroleum potential of Wilderness Lands in California, by Edward W. Scott

E. Petroleum potential of Wilderness Lands in Colorado, by Charles W. Spencer

F. Petroleum potential of Wilderness Lands in Idaho, by Charles A. Sandberg

G. Petroleum potential of Wilderness Lands in Montana, by William J. Perry, Jr., Dudley D. Rice, and Edwin K. Maughan

H. Petroleum potential of Wilderness Lands in Nevada, by Charles A. Sandberg

I. Petroleum potential of Wilderness Lands in New Mexico, by Robert T. Ryder

J. Petroleum potential of Wilderness Lands in Oregon, by Thomas D. Fouch

K. Petroleum potential of Wilderness Lands in Utah, by Cornelius M. Molenaar and Charles A. Sandberg

L. Petroleum potential of Wilderness Lands in Washington, by Thomas D. Fouch

M. Petroleum potential of Wilderness Lands in Wyoming, by Charles W. Spencer, with a section on The Wyoming part of the Wyoming-Utah-Idaho thrust belt, by Richard B. Powers

N. Petroleum potential of Wilderness Lands in Wyoming-Utah-Idaho thrust belt, by Richard B. Powers

O. Probabilistic methodology for petroleum resource appraisal of Wilderness Lands, by Robert A. Crovelli

P. Estimates of the potential petroleum resources in Wilderness Lands, by Betty M. Miller

Conclusions, by Betty M. Miller

Appendix 



\title{
Petroleum Potential of Wilderness Lands in the Western United States
}

\author{
By Betty M. Miller
}

\section{ABSTRACT}

In 1982-83, the U.S. Geological Survey (USGS) conducted an investigation of the oil and gas potential of the designated and proposed Wilderness Lands in the Western United States. The scope of this study was limited to the assessment of conventional recoverable petroleum resources occurring in the designated and proposed Wilderness Lands of the Western United States that are administered under four Federal agencies: Bureau of Land Management (BLM), U.S. Forest Service (USFS), National Park Service (NPS), and Fish and Wildlife Service (FWS).

The total area of the study included approximately 74 million acres of Wilderness Lands in these 11 Western States: Arizona, California, Colorado, Idaho, Montana, Nevada, New Mexico, Oregon, Utah, Washington, and Wyoming. The 74 million acres represent 31 percent of the total Federal lands within these 11 Western States. Approximately 49 percent of all the lands in these States are federally owned.

The objective of this study was to assemble through various means all the available pertinent information that could be brought together within the USGS and integrate these data into a computer-based digital cartographic data system that was focused upon the single issue of reviewing the known geological and geophysical data to determine the geologic characteristics favorable or unfavorable for the occurrence of petroleum resources in these Wilderness Lands. In a joint effort in the USGS between the Geologic Division (GD) and the National Mapping Division (NMD) all of the mappable information used in this study was prepared and processed by using digital cartographic techniques. These include digitizing the location and boundaries of the Wilderness Lands; acreage calculations; the boundaries of the USGS petroleum provinces; and the geologic and tectonic boundaries within each petroleum province and State. In addition, searches were conducted on well data files which provided the locations and geologic information on over 5,000 wells drilled within or immediately adjacent to the Wilderness Lands.
An analysis of all the geologic characteristics favorable or unfavorable for petroleum occurrence in conjunction with the geologic settings for the Wilderness Lands scattered within the framework of the petroleum provinces was performed by a team of geologists on each of the wilderness tracts. The geologic characteristics reviewed for each tract included the presence or absence of the following: adequate source beds and reservoir rocks; adequate trapping mechanisms; favorable thermal and maturation histories; presence of petroleum seeps or adjacent wells with shows or production; and the presence of favorable sedimentary rock sections underlying volcanic terrane or faulted and overthrust areas.

A description of the geology and geologic framework is provided for each State along with an explanation of the interpretative geology and evaluation of the petroleum potential within the locale of each of the wilderness tracts.

The assessment of the petroleum resources on the Wilderness Lands was completed in two separate stages. In the first stage the geologists evaluated the geological characteristics for the favorability or lack of favorability for the occurrence of oil and natural gas within each wilderness tract and assigned a qualitative rating for each tract's potential for the occurrence of recoverable oil and gas resources. In the second stage in evaluating the petroleum potential for the wilderness tracts, an effort was made to arrive at a quantitative assessment within the framework of the USGS's latest published resource estimates which are made on a province basis. The geologic characteristics evaluated for the favorability of petroleum occurrence within each of the clusters of wilderness tracts were the determining factors for the subjective assessments of the petroleum potential for each wilderness tract occurring within the respective basin or province. The quantitative resource assessments are subjectively determined as to the richness and potential of the wilderness tracts relative to the total petroleum potential for the respective petroleum province within which they occur.

The results of the qualitative analysis of the petroleum potential of the Wilderness Lands are tabulated by total acreages 
for each wilderness tract as classified by its potential rating. These tabulations are made for the Wilderness Lands by petroleum province, by State, and for the total Wilderness Lands in the 11 Western States. A summary is provided of the petroleum potential by acreage for all the Wilderness Lands in the Western United States by State and for the total 11 States. At least 34 percent of the total acreage for Wilderness Lands, or approximately 25 million acres, may have the geologic characteristics necessary for the occurrence of petroleum resources in varying amounts (high, medium, and low potential). An additional 33 percent of the Wilderness Lands may have some limited potential where small sedimentary areas are mixed within igneous and metamorphic terranes, but are more likely to fall in the low to zero potential. Finally, 33 percent of the Wilderness Lands probably have no petroleum potential because they are located in terranes with predominantly igneous and (or) metamorphic rocks that are unfavorable for the occurrence of petroleum.

The quantitative petroleum assessments for the Wilderness Lands in the Western United States represent a part of the total estimate of the remaining undiscovered oil and natural gas for the 38 petroleum provinces, as defined by Dolton and others in USGS Circular 860 in 1981, within which the Wilderness Lands occur. The undiscovered recoverable oil for the Wilderness Lands in the Western States is estimated to range from 0.555 to 1.490 billion barrels with a mean estimate of 0.834 billion barrels. The undiscovered recoverable natural gas is estimated to range from 5.536 to $\mathbf{1 6 . 6 3 9}$ trillion cubic feet with a mean estimate of 9.729 trillion cubic feet. Each range corresponds to the 95 and 5 percent probabilities of more than the respective amounts. The estimates reported at the 95 percent and 5 percent probabilities and the mean estimates for oil and gas are summarized for the separate States and the aggregated totals.

A series of printed maps, one for each Western State, accompanies this report (Miscellaneous Investigations Series Maps I-1537-I-1547, in press) and shows in color the location and qualitative petroleum potential of the Wilderness Lands studied, with BLM identification of tracts; the boundary locations of all major Federal and Indian lands; the boundaries and identification of the USGS petroleum provinces; and other base information. A pamphlet will accompany each State map describing the geology of the State and the local geology relative to the position of the wilderness tracts and their petroleum potential. These maps were compiled by using traditional cartographic techniques from digitally produced graphics and are published as separate sheets for each State at a scale of $1: 1,000,000$.

\section{ACKNOWLEDGMENTS}

The integration of a vast quantity of information that went into this petroleum assessment of the Wilderness Lands in the Western United States required the involvement and expertise of a team of USGS scientists. We wish to thank the following people for their contributions:

Geologic Division

Office of the Chief Geologist

Reston, Virginia

B. M. Miller
Office of Energy and Marine Resources

Branch of Oil and Gas Resources

Reston, Virginia

R. T. Ryder

Denver, Colorado

R. A. Crovelli

T. D. Fouch

E. K. Maughan

C. M. Molenaar

W. J. Perry, Jr.

R. B. Powers

D. D. Rice

C. A. Sandberg

C. W. Spencer

Yorba Linda, California

E. W. Scott

Office of Regional Geology

Branch of Central Regional Geology

Denver, Colorado

S. S. Oriel

E. T. Ruppel

Office of Mineral Resources

Branch of Central Mineral Resources

Denver, Colorado

C. H. Thorman

O. L. Tweto

National Mapping Division

Eastern Mapping Center

Branch of Data Management

Reston, Virginia

D. E. Clark

M. A. Domaratz

D. P. Huber

G. A. Manuel

D. W. Painter

J. M. Stapleton

Branch of Cartometrics, Section 3, Unit 2

Reston, Virginia

M. T. Cooley

T. N. Mecklenburg

P. D. Tate

Office of Systems and Techniques Development

Branch of Technical Management

Reston, Virginia

J. H. Wittmann.

Our acknowledgments to the clerical and technical support staffs in both the Geologic Division and the National Mapping Division. R. H. Balay, R. W. Dawson, and H. A. Hays, technical staff in Denver, Colorado, provided valuable assistance in computer processing and other computer-related tasks necessary for the completion of this study. 